\title{
SISTEM INFORMASI PENGOLAHAN DATA STATUS GIZI PADA BALITA DI UPTD PUSKESMAS HARAPAN RAYA
}

\author{
Refni Wahyuni1 ${ }^{1)}$, Yuda Irawan ${ }^{2)}$ \\ ${ }^{1}$ Teknik Informatika, STMIK Hang Tuah Pekanbaru \\ email: refniabid@gmail.com \\ ${ }^{2}$ Sistem Informasi, STMIK Hang Tuah Pekanbaru \\ email: yudairawan89@gmail.com
}

\begin{abstract}
Health center are the spearhead in the realization of the vision and mission of the Department of Health which among other is to improve the performance Health Center, by increasing public access to quality health services, monitoring and health information systems. In Harapan Raya Health Center, these processes must be done manually will require a longer time and have a risk of errors can occur in the process that will ultimately affect the performance of the respective health center. Process models to be used in Information Systems Data Processing In Toddlers Nutritional Status is based paradigm waterfall consisting of Systems Engineering, Requirements Analysis, Design, Coding, Testing, Implementation and Maintenance. In the construction of this information system, the authors use the Java programming language and MYSQL as the database. Results of this research is the application of Information Systems Data Processing In Toddlers Nutritional Status In Harapan Raya Health Center more effective and accurate to assist officers in processing data nutrition nutritional status of children in the health center.
\end{abstract}

Keywords : Information Systems, Nutritional Status, Java, MySQL

\begin{abstract}
Abstrak
Puskesmas merupakan ujung tombak dalam merealisasikan visi dan misi Departemen Kesehatan yang diantaranya adalah meningkatkan kinerja Puskesmas, dengan cara meningkatkan akses masyarakat terhadap pelayanan kesehatan yang berkualitas, monitoring dan sistem informasi kesehatan. Pada Puskesmas di Harapan Raya, proses-proses tersebut dilakukan secara manual tentunya akan memerlukan waktu yang lebih lama serta memiliki resiko kesalahan dapat terjadi pada proses tersebut sehingga pada akhirnya akan berdampak pada kinerja Puskesmas yang bersangkutan. Model proses yang akan digunakan dalam Sistem Informasi Pengolahan Data Status Gizi Pada Balita ini berdasarkan paradigma waterfall yang terdiri dari Systems Engineering, Requirements Analysis, Design, Coding, Testing, Implementation dan Maintenance. Dalam pembangunan Sistem Informasi ini, penulis menggunakan bahasa pemrograman Java dan MySQL sebagai database. Hasil penelitian ini berupa aplikasi Sistem Informasi Pengolahan Data Status Gizi Pada Balita di UPTD Puskemas Harapan Raya yang lebih efektif dan akurat untuk membantu petugas gizi dalam mengolah data status gizi balita di Puskesmas.
\end{abstract}

Keywords : Sistem Informasi, Status Gizi, Java, MySQL 


\section{PENDAHULUAN}

Perkembangan perekonomian yang semakin pesat tidak dapat dipisahkan oleh perkembangan teknologi, terutama teknologi informasi komputerisasi. Dengan sistem informasi menggunakan teknologi komputer akan memudahkan sebuah instansi untuk melakukan pengolahan data dan suatu hasil informasi yang dihasilkan akan sangat akurat, cepat, mudah dipahami, berguna dan bermanfaat bagi instansi tersebut. Sistem informasi yang baik akan mendatangkan manfaat yang baik bagi organisasi atau instansi maka diperlukan suatu media atau alat pendukung yang dapat menyajikan informasi tersebut yang tak lain lagi adalah komputer.

UPTD Puskesmas Harapan Raya merupakan sebuah instansi yang bergerak dibidang kesehatan. Puskesmas ini menjalin kerjasama dengan Dinas Kesehatan untuk melayani kesehatan masyarakat. Oleh karena itu, proses dan analisis status gizi yang dilakukan puskesmas tersebut berdasarkan permintaan bidan dan ahli gizi serta kesepakatan dengan pihak Dinas Kesehatan. diantaranya yaitu dalam hal pencatatan data balita sehingga sering terjadinya kesalahan data. Pencatatan data balita dilakukan petugas gizi dengan buku atau form yang telah di sediakan yang kemudian buku atau form tersebut akan dibuat menjadi arsip. Hal tersebut menyebabkan waktu yang cukup lama dalam pengolahan data status gizi balita dan pencatatan data balita. Hal tersebut mengakibatkan terjadinya kemungkinan kesalahan data dan penumpukan arsip-arsip di konsultasi gizi. Proses pembuatan laporan juga menjadi masalah tersendiri karena memakan waktu yang cukup lama. Hal ini karena laporan dan sumber-sumber laporannya masih berupa laporan tertulis.

Berdasarkan dari uraian diatas, tergambar adanya topik yang cukup menarik untuk diteliti. Oleh karena itu, peneliti tertarik untuk melakukan penelitian dengan judul: "Sistem Informasi Pengolahan Data Status Gizi

Pada Balita Di Uptd Puskesmas Harapan Raya”.

\section{METODE PENELITIAN}

Dalam penelitian ini, peneliti menggunakan metode Waterfall yang terdiri dari Systems Engineering, Requirements Analysis, Design, Coding, Testing, Implementation dan Maintenance. Ketujuh tahapan tersebut secara diagram dapat dilihat seperti gambar 1 di bawah ini:

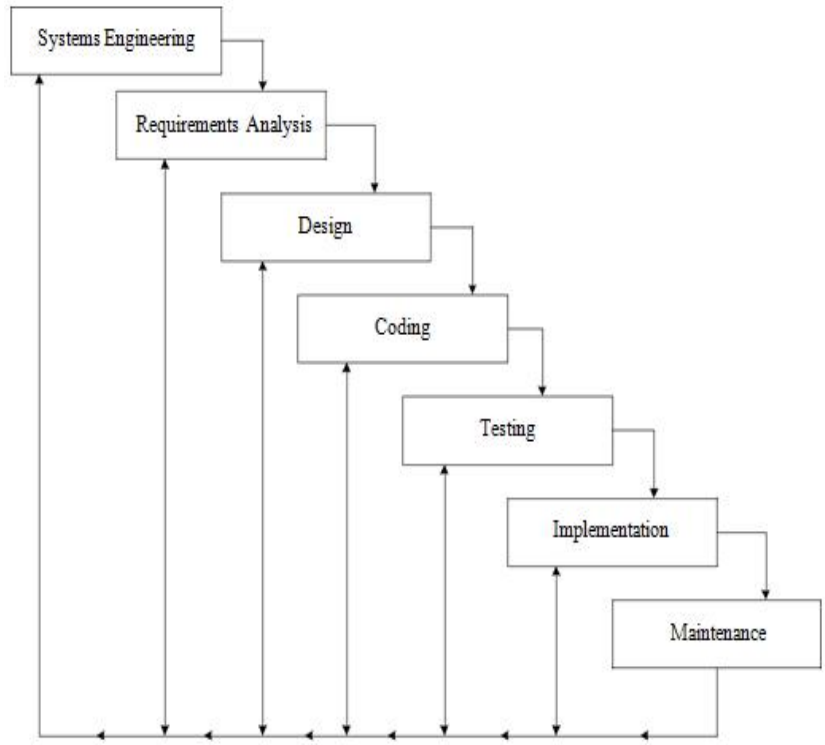

Gambar 1 Diagram Metode Waterfall menurut, (Bennett dkk, 2002) 

yaitu:

Tahap-tahap dari metode waterfall ini memetakan kegiatan-kegiatan pengembangan dasar,

1. Keahlian Analisis Sistem (Systems Enginering)

Kebutuhan dari Sistem Informasi Pengolahan Data Status Gizi Pada Balita di UPTD Puskesmas Harapan Raya diidentifikasi, dianalisa, diatur dan dijadwalkan. Setelah itu baru diseleksi bagian yang akan dibuat sistem informasi. Yang menjadi responden dalam tahapan identifikasi ini adalah Petugas Gizi dan Petugas yang ada pada UPTD Puskesmas Harapan Raya. Data dan informasi dikumpulkan melalui pengamatan, wawancara maupun dari dokumen dan laporan yang telah ada. Dari hasil identifikasi ditemukan beberapa keterbatasan pada Sistem Informasi lama pada Pengolahan Data Status Gizi Pada Balita di UPTD Puskesmas Harapan Raya seperti yang telah diuraikan pada bagian sebelumnya, yakni pencatatan data, penyimpanan dan pencarian data masih dilakukan secara manual, dan distribusi data antar bagian yang kurang efisien. Sistem baru direncanakan akan meningkatkan efektifitas dan efisiensi kerja para Petugas Gizi serta pertanggungjawaban kepada pemimpin UPTD Puskesmas Harapan Raya.

2. Analisis Kebutuhan (Requirements Analysis)

Penulis melakukan analisa tentang sistem yang sedang digunakan pada UPTD Puskesmas Harapan Raya, kemudian diubah dan disempurnakan ke sistem yang lebih efisien. Pada siklus ini terdapat tiga tahapan yaitu:

a. Requirement Determination, para petugas gizi diikut sertakan dalam menentukan kebutuhan ataupun permintaan terhadap sistem informasi baru yang akan dibangun. Selain itu, penulis juga mempelajari sistem manual yang diterapkan pada UPTD Puskesmas Harapan Raya saat ini, baik dalam hal pengolahan data maupun distribusi data dan laporan.

b. Requirement Structuring, pada tahap ini peneliti membuat diagram aliran sistem informasi lama dari data dan informasi yang telah didapat dari UPTD Puskesmas Harapan Raya. Dari hasil analisa, dibuat aliran sistem informasi baru dan context diagram baru. Disini ditentukan komponen sistem yang akan dibuat secara komputerisasi.

c. Alternative Generation and Selection Design, penulis membuat alternatif rancangan sesuai dengan keinginan petugas gizi UPTD Puskesmas Harapan Raya untuk dibandingkan dan dipilih sesuai dengan biaya, sumber daya manusia dan teknis yang ada.

3. Perancangan (Design)

Setelah sistem yang ada dianalisa dan sudah sesuai dengan kebutuhan petugas gizi UPTD Puskesmas Harapan Raya, maka selanjutnya adalah disain menggunakan Data Flow Diagram (DFD) dan Entity Relationship Diagram (ERD) untuk menentukan aliran data yang akan diproses oleh sistem informasi baru sebagai alat bantu untuk membangun Sistem Informasi Pengolahan Data Status Gizi Pada Balita di UPTD Puskesmas Harapan Raya.

4. Pembuatan Program (Coding)

Pada tahapan ini pengembang mendisain bentuk form input data seperti data balita, posyandu, paremedis, dan data pemeriksaan status gizi balita serta bentuk laporan-laporan yang userfriendly seperti laporan bulanan status gizi balita.Disini penulis menggunakan bahasa pemrograman Java dengan NetBeans sebagai perangkat lunaknya dan MySql sebagai media penyimpanan data.

5. Pengujian (Testing)

Tahapan dimana sistem yang baru diuji kemampuan dan keefektifannya oleh bidang konsultasi gizi UPTD Puskesmas Harapan Raya, sehingga didapatkan kekurangan dan kelemahan sistem yang kemudian dilakukan pengkajian ulang dan perbaikan terhadap aplikasi menjadi lebih baik dan sempurna. Pada tahap ini, akan diuji kinerja dari sistem yang dibuat, semua bagian di lakukan pengetesan secara bebas.

Proses-proses yang tersedia yaitu proses pengolahan, pemutahiran data, proses penyimpanan, dan proses pencetakan laporan data balita, laporan data posyandu, laporan paramedis, dan laporan pemeriksaan status gizi balita. Untuk memastikan kepuasan 
terhadap ketepatan kebutuhan sistem yang telah dibuat dan kelengkapannya. Pada kajian ini pengujian tidak dilakukan.

6. Pengembangan (Implementation)

Sistem informasi diinstal dan didukung oleh bidang konsultasi gizi UPTD Puskesmas Harapan Raya. Dokumentasi, pelatihan dan bantuan diberikan pada petugas gizi. Disini bidang konsultasi gizi UPTD Puskesmas Harapan Raya akan mencoba memakai sistem yang telah dibuat atau diinstal. Selama percobaan akan diawasi oleh pembuat sistem atau programmer. Penelitian yang dilakukan masih belum melalui tahapan ini.

7. Pemeliharaan (Maintenance)

Sistem informasi yang sudah diinstal di Konsultasi Gizi UPTD Puskesmas Harapan Raya diperlukan pemeliharaan dan pembaharuan sesuai kebutuhan pihak Konsultasi Gizi UPTD Puskesmas Harapan Raya seiring berjalannya waktu. Pada tahapan ini adalah kelanjutan sistem informasi baru yang sudah dijalankan. Programmer memelihara dan memperbaiki kekurangan dari sistem informasi baru. Penelitian yang dilakukan masih belum melalui tahapan ini.

\section{Teknik Pengumpulan Data}

Untuk analisis dan perancangan Sistem Informasi Pengolahan Data Status Gizi Pada Balita di UPTD Puskesmas Harapan Raya akan dikumpulkan data-data sekunder dan primer yang diperoleh dari UPTD Puskesmas Harapan Raya yang dilakukan dengan melakukan observasi langsung serta petugas gizi dan petugas yang ada pada UPTD Puskesmas Harapan Raya. Berikut ini merupakan jenis data yang digunakan dalam penelitian ini adalah sebagai berikut:

\section{Data Primer}

Melakukan wawancara dan observasi di bagian administrasi dan bidang konsultasi gizi untuk mengetahui alur kinerja sistem yang sedang berjalan serta fungsi-fungsi setiap bagian pada UPTD Puskesmas Harapan Raya.

b. Data Sekunder

Dikumpulkan dengan mempelajari dokumen. Data yang dikumpulkan adalah data balita, data posyandu, data paramedis, data pemeriksaaan status gizi balita, data status gizi balita serta bentuk laporan balita, laporan posyandu, laporan paramedis, laporan pemeriksaaan balita, laporan status gizi balita.

\section{HASIL DAN PEMBAHASAN}

Dari hasil pembuatan Sistem Informasi Pengolahan Data Status Gizi Pada Balita di UPTD Puskesmas Harapan Raya. Maka dihasil kan proses pengolahan data status gizi balita yang lebih cepat dan tepat, hal ini disebabkan sudah tersedianya sistem yang mendukung dalam pengolahan data yang lebih baik dari yang sebelum nya dan juga sangat menghemat waktu dalam proses yang selama ini memakan waktu dalam proses nya. Bisa kita lihat sekarang ini komputer sudah memasuki segala lapisan masyarakat. 


\section{Spesifikasi Program}

\section{Tampilan Login}

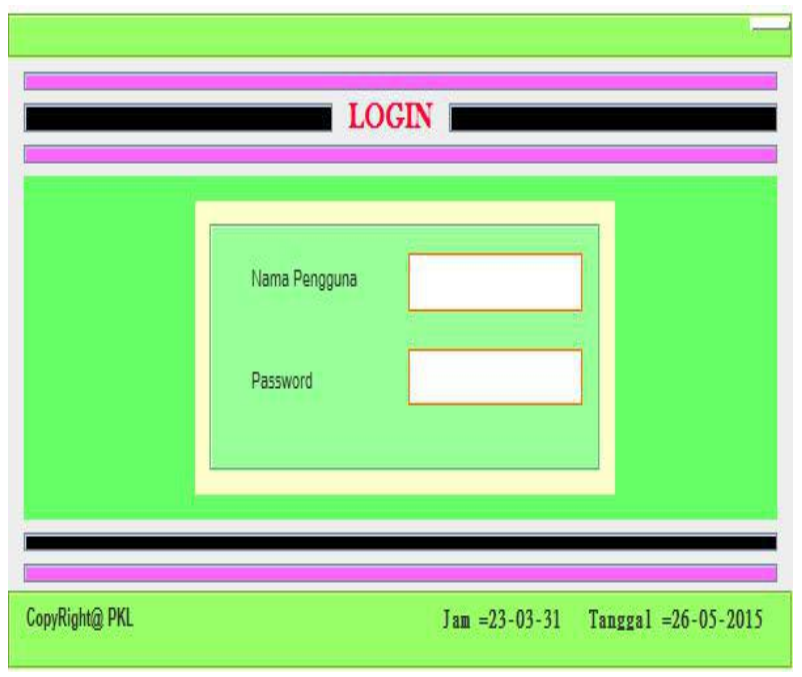

Gambar 1 Tampilan Login

Pada halaman login digunakan untuk masuk ke halaman Menu Utama, jika salah satu data ( username, password ) yang dimasukan salah maka tidak akan bisa masuk ke halaman Menu Utama.

\section{Tampilan Menu Utama}

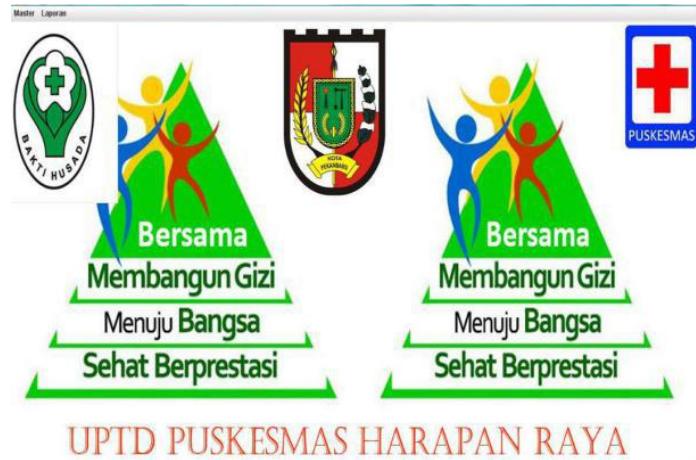

Gambar 2. Tampilan Menu Utama

Pada halaman menu utama ini terdapat menu navigasi yaitu Master dan Laporan. Pada master terdapat data balita, data posyandu, data paramedis, data pemeriksaan dan data status gizi. Sedangkan pada laporan terdapat laporan balita, laporan posyandu, laporan paramedis, laporan pemeriksaan dan laporan status gizi. 


\section{Tampilan Data Balita}

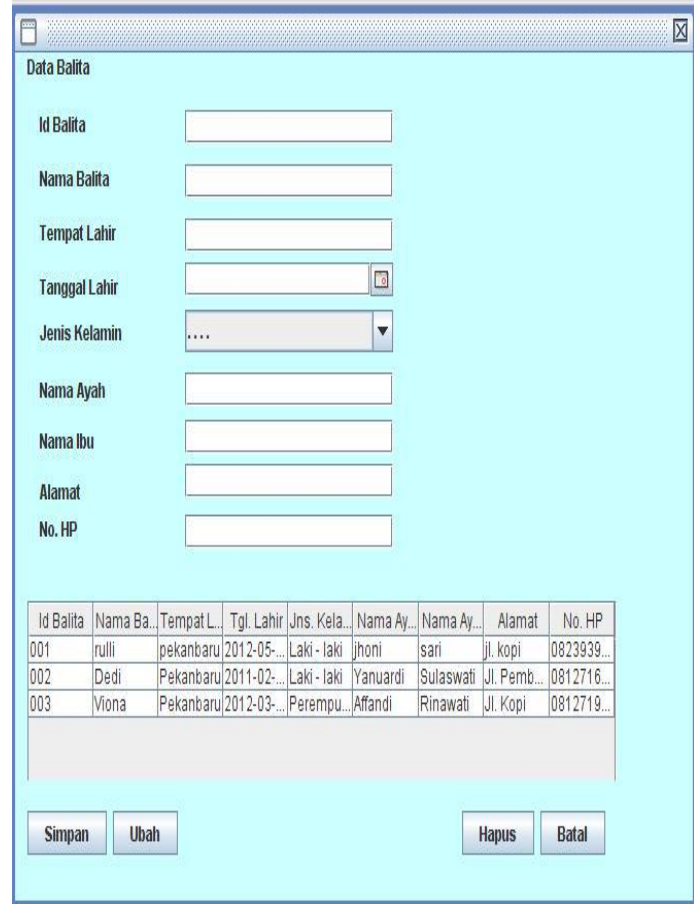

Gambar 3. Tampilan Data Balita

Pada halaman ini digunakan untuk menambahkan data Balita yang terdiri dari id balita, nama balita, tempat lahir, tanggal lahir, jenis kelamin, nama ayah, nama ibu, alamat dan no. Hp.

\section{Tampilan Data Paramedis}

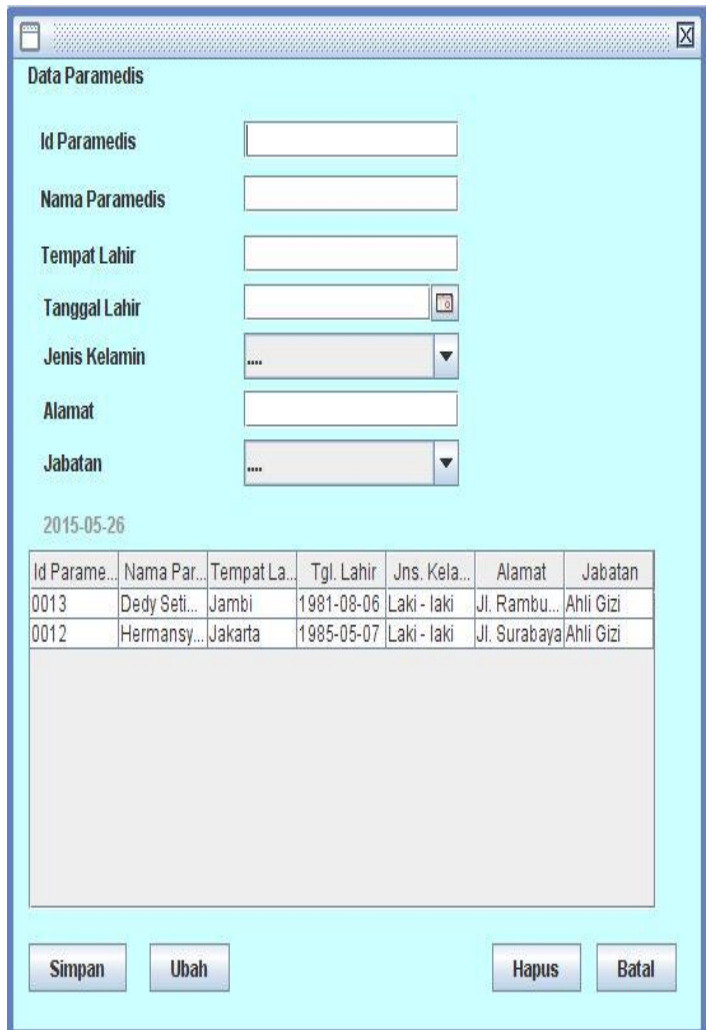

Gambar 5. Tampilan Data Paramedis 
Pada halaman ini digunakan untuk menambahkan data paramedis yang terdiri dari id paramedis, nama paramedis, tempat lahir, tanggal lahir, jenis kelamin, alamat dan jabatan.

\section{Tampilan Data Pemeriksaan}

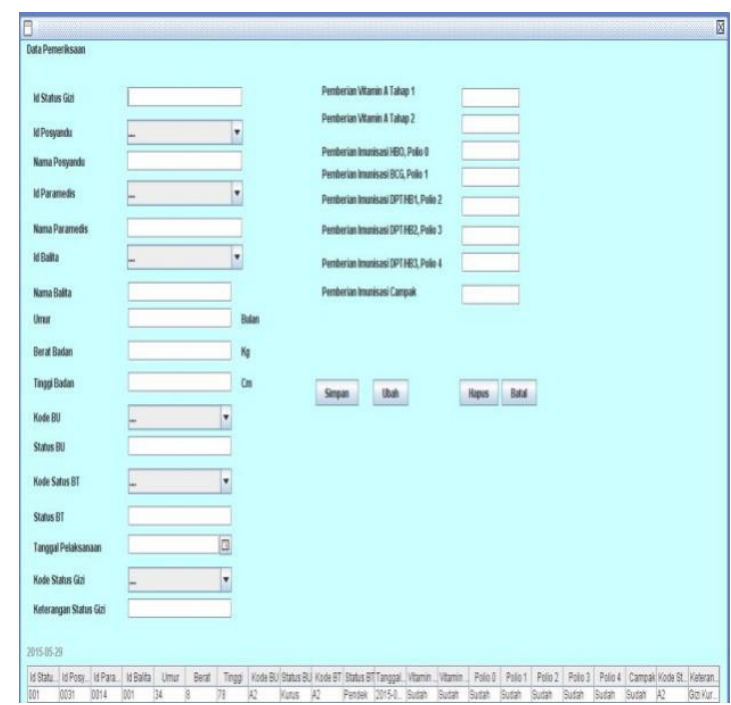

Gambar 6 Tampilan Data Pemeriksaan

Pada halaman ini digunakan untuk menambahkan data pemeriksaan yang terdiri dari id status, id posyandu, id paramedis, id balita, nama balita, umur, jenis kelamin, berat badan, tinggi badan kode BU, status BU, kode BT, status BT, tanggal pemeriksaan, kode status gizi, dan keterangan status gizi.

\section{Tampilan Data Status Gizi}

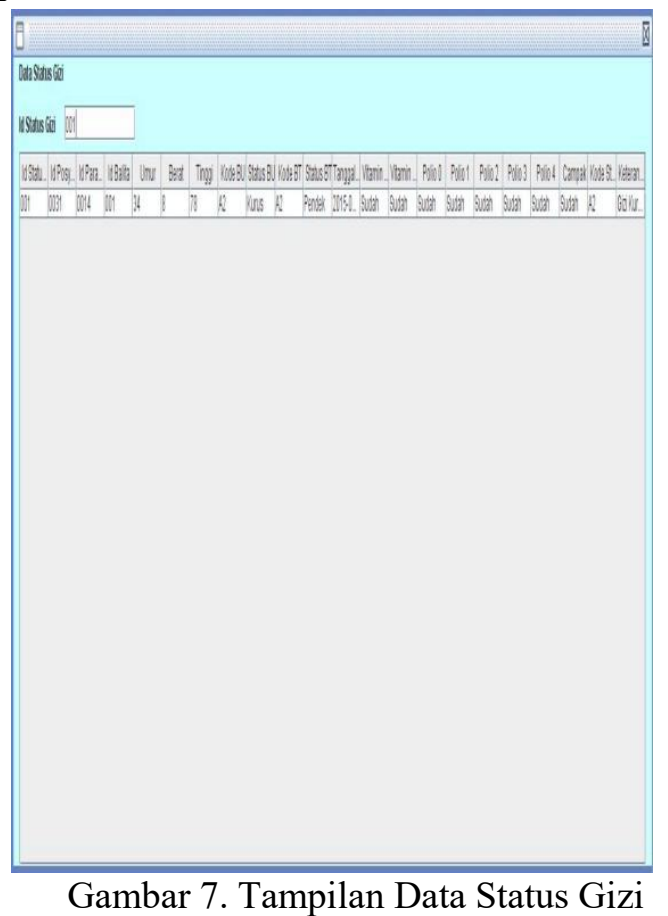

Pada halaman ini digunakan untuk mempilkan data status gizi yang terdiri id status, id posyandu, nama posyandu, id paramedis, nama paramedis, id balita, umur, jenis kelamin, berat badan, tinggi badan kode BU, status BU, kode BT, status BT, tanggal pemeriksaan, kode status gizi, dan 
keterangan status gizi, pemberian vitamin A tahap 1, pemberian vitamin A tahap 2, pemberian imunisasi HBO, Polio 0, pemberian imunisasi BCG, Polio 1, pemberian imunisasi DPT/HB1, Polio 2, pemberian imunisasi DPT/HB1, Polio 3, pemberian imunisasi DPT/HB1, Polio 4, dan pemberian imunisasi campak, kode status gizi, dan keterangan status gizi.

\section{Tampilan Laporan Data Balita}
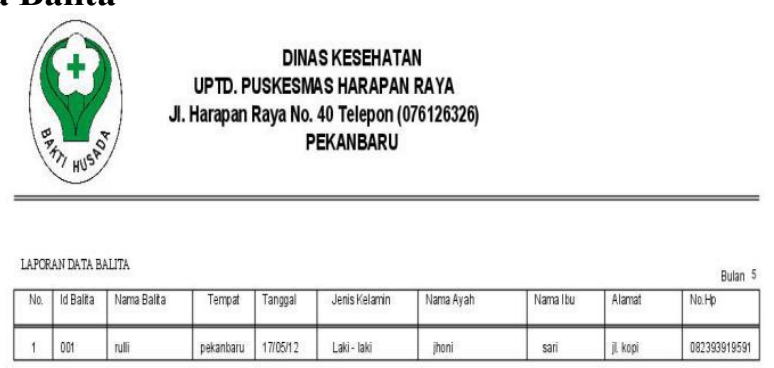

Peknowav, 16 Juni 2015

Gambar 8. Tampilan Laporan Data Balita

\section{Tampilan Laporan Data Posyandu}

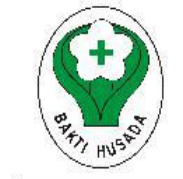

DINAS KESEHATAN

UPTD. PUSKESMAS HARAPAN RA YA

JI. Harapan Raya No. 40 Telepon (076126326 PEKANBARU

\begin{tabular}{|c|c|c|c|c|c|c|c|}
\hline No & Id Possandu & Nama Posjandu & RT & RW & Kelurahan & $\begin{array}{c}\text { Nama } \\
\text { Penangaungiazu ab }\end{array}$ & Aamat \\
\hline 1 & 0031 & Anggrek I & 001 & 005 & Tangkerang Selatan & Ida Fadhila & Ju. Harapan \\
\hline 2 & 0032 & Anggrek II & 003 & 008 & Bukkt Raya & Si Rahmawati & Ji. t. .Bey \\
\hline 3 & 0033 & Anggrek III & 002 & 008 & Simp ang Tiga & Sri Wahyuni & J. T. Bey \\
\hline 4 & 0034 & Anggrek IV & 003 & 001 & Simpang Tiga & Ida & Ju. Harpan \\
\hline 5 & 0035 & Melati 1 & 001 & 002 & Simpang Tiga & Rahayu & JL. Jati \\
\hline
\end{tabular}

Pekanbaru, 16 Juni 2015

di. Ind Whati

Gambar 9. Tampilan Laporan Data Posyandu

\section{Tampilan Laporan Data Status Gizi}

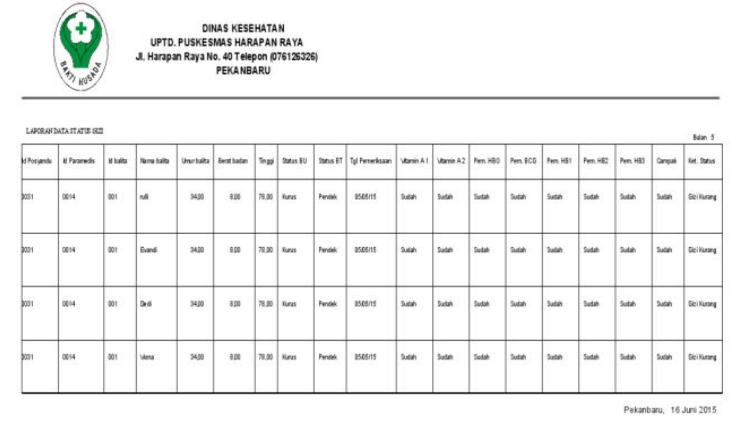

Gambar 10. Tampilan Laporan Data Status Gizi 


\section{SIMPULAN DAN SARAN}

\section{Kesimpulan}

Berdasarkan penelitian yang dilakukan oleh penyusun mengenai perancangan dan implementasi sistem informasi status gizi pada balita di UPTD Puskesmas Harapan Raya, maka dapat ditarik beberapa kesimpulan sebagai berikut :

1. Sistem informasi pengolahan data status gizi pada balita ini mampu mengolah data dan menyimpan data, sehingga dapat dicari dengan mudah dan tidak memakan waktu yang cukup lama.

2. Dengan adanya sistem informasi ini pengolahan data status gizi balita akan terintegrasi dalam satu database yang lebih efektif dan efisien.

3. Mengurangi terjadinya kehilang data dan mempercepat proses penyampaian laporan status gizi balita.

\section{Saran}

Untuk lebih meningkatkan kinerja dari sistem informasi status gizi pada balita di UPTD Puskesmas Harapan Raya ini penulis mengusulkan beberapa saran yang dapat dijadikan pertimbangan, yaitu:

1. Sistem informasi status gizi pada balita ini dapat dikembangkan lebih lanjut, sehingga informasi yang disajikan dapat lebih jelas, lebih lengkap seperti penambahan imunisasi serta gizi ibu hamil.

2. Sistem infomasi ini dapat dikembangkan secara online atau berbasis web dengan bahasa pemograman seperti PHP dan database oracle.

\section{DAFTAR PUSTAKA}

[1] Abdul Kadir, Tera CH. Triwahyuni (2013). Pengantar teknologi informasi: Yogyakarta : CV. Andi Offset.

[2] Irawan, Y., Rahmalisa, U., Wahyuni, R., \& Devis, Y. (2019). Sistem Informasi Penjualan Furniture Berbasis Web Pada CV. Satria Hendra Jaya Pekanbaru. JTIM: Jurnal Teknologi Informasi dan Multimedia, 1(2), 150-159.

[3] Jogiyanto, (2005). "Pengenalan komputer", Yogyakarta : CV. Andi Offset. (andi).

[4] Abdul Kadir, (2012). Algoritma dan pemrograman menggunakan Java: Yogyakarta : CV. Andi Offset.

[5] Irawan, Y. (2017). Sistem Pendukung Keputusan Untuk Penilaian Prestasi Belajar Siswa Pada Sekolah Dasar Negeri 167 Pekanbaru Dengan Metode Analytical Hierarchy Process (AHP). Jurnal Ilmu Komputer, 6(2), 85-90.

[6] Hussein, O. S., Wahyuni, R., \& Mukhtar, H. (2018). Sistem informasi deteksi kehadiran dan media penyampaian pengumuman dosen dengan menggunakan teknik pengenalan QR code. Rabit: Jurnal Teknologi dan Sistem Informasi Univrab, 3(2), 85-92.

[7] Irawan, Yuda. "Aplikasi E-Commerce Untuk Pemasaran Kerajinan Tangan Usaha Kecil Menengah (UKM) di Riau Menggunakan Teknik Dropshipping." Jurnal Ilmiah Core IT: Community Research Information Technology 7.1 (2019).

[8] Jurnal Gizi Klinik Indonesia - Vol. 5 No. 2 November 2008, ISSN 1693-900X Jurnal Kesehatan, ISSN 1979-7621, Vol. 3, No. 1, Juni 2010: 58-65 Jurnal Ilmiah SINUS ISSN : $1693-1173$

[9] Irawan, Y. (2019). Sistem Informasi Pemasaran Busana Syar'i dengan Penerapan Customer Relationship Management (CRM) Berbasis Web. INTECOMS: Journal of Information Technology and Computer Science, 2(1), 1-9. https://doi.org/https://doi.org/10.31539/intecoms.v2i1.629 